\title{
A PRIMAVERA JUVENIL NO BRASIL E NO MUNDO: O "SENSO DE POSSIBILIDADE” E O SENTIDO DA “PÓS-HISTÓRIA” EM JOGO NO APROFUNDAMENTO DO SENTIDO DA DEMOCRACIA
}

\author{
THE SPRING OF YOUTH IN BRAZIL AND IN THE WORLD: THE "SENSE OF \\ POSSIBILITY"AND THE MEANING OF "POST-HISTORY" INVOLVED IN \\ THE DEEPENING OF THE MEANING OF DEMOCRACY
}

\author{
Mônica G. T. do Amaral ${ }^{1}$ \\ Tiago L. Ferreira ${ }^{2}$
}

\begin{abstract}
RESUMO
Este artigo propõe uma reflexão a respeito das manifestações juvenis de junho de 2013 no Brasil, em que analisa seu papel no aprofundamento do sentido de democracia, inspirando-se nas ideias de Robert Musil sobre o "senso de possibilidade" e no debate sobre a "pós-história", tal como propõe Vilém Flusser. Comparando-as com a Primavera Árabe, procura-se abordar criticamente as interpretações apresentadas sobre o fenômeno, tanto de intelectuais brasileiros, como do estrangeiros, tomando como base as ideias desses autores, ou mesmo as análises sobre o papel das "redes sociais" e das "tecnoimagens" no desencadeamento de manifestações de massa lideradas por uma juventude ávida por encontrar canais de participação efetivos. Ressalta-se a atualidade de Flusser para pensar a crise da experiência, sobretudo em países como o nosso, onde a dominância da cultura africana confere novos sentidos ao engajamento político e à vida social, pautados pela estética e a sabedoria ancestral de culturas não ocidentais.
\end{abstract}

Palavras-chave: Manifestações juvenis. Tecnoimagens. Pós-história e estética africana.

\begin{abstract}
This article proposes a reflection about the protests led by the youth in June of 2013 in Brazil, analyzing their role in the deepening of the meaning of democracy. This reflection is inspired by the ideas of Robert Musil on the "sense of possibility" and debates on "post- history", such as those proposed by Vilém Flusser. Comparing these protests with those of the Arab Spring, we seek to look critically at the interpretations presented on the phenomenon both by Brazilian and foreign intellectuals, basing our critique on the ideas of these authors, or even on analyses of the role of "social networks" and "techno-images" in the triggering the protests of the mass, which were led by the youth, eager to find effective channels of participation. The article emphasizes the relevance of Flusser in thinking about the crisis of experience, especially in countries like Brazil, where the dominance
\end{abstract}

1 Professora Livre-Docente da Faculdade de Educação da USP, Docente do Programa de Pós-Graduação em Educação da FEUSP e Membro Associado da Sociedade Brasileira de Psicanálise (SBPSP).

2 Doutorando do Programa de Pós-Graduação em Educação da FEUSP, Mestre em Educação pelo mesmo Programa, Bacharel em Ciências Sociais pela FFLCH-USP. 
of the African culture gives new meaning to political engagement and social life, guided by the aesthetics and ancient wisdom of non-Western cultures.

Keywords: Youth protests. Techno-images. Post-history and African aesthetics.

\section{Introdução}

Iniciamos esta apresentação pelas ideias antecipadas por Robert Musil (1938, 2006) em seu romance $O$ Homem sem qualidades, que, de modo agudo, anuncia o terreno em que se forjaria o homem fluido de hoje, o qual, segundo ele, seria guiado muito mais pelo senso de possibilidade do que pelo senso de realidade, proclamado pelo pensamento pragmático burguês. Vejamos o que diz o autor sobre o senso de possibilidade:

Quem o possui não diz, por exemplo: aqui aconteceu, vai acontecer, tem de acontecer isso ou aquilo; mas inventa: aqui poderia, deveria ou teria de acontecer isto ou aquilo; e se lhe explicarmos que uma coisa é como é, ele pensa: bem provavelmente também poderia ser de outro modo. Assim, o senso de possibilidade poderia ser definido como a capacidade de pensar tudo aquilo que também poderia ser, e não julgar que aquilo que é seja mais importante do que aquilo que não é (2006, p.34).

Podemos dizer que o escritor apontava para a abertura necessária no interior do pensamento ocidental para se pensar a utopia perante a vacuidade da experiência. Pouco tempo antes, logo após o fim da $1^{\text {a }}$ Guerra Mundial, o filósofo Walter Benjamin $(1969,1980)$ anunciara o fim da experiência e da arte de narrar. Em “O Narrador”, questiona:

Com a Guerra Mundial começou a manifestar-se um processo que desde então não se deteve. Não se notou, no fim da guerra, que as pessoas chegavam mudas do campo de batalha - não mais ricas, mas mais pobres em experiência comunicável? (1980, p.57).

O pensador alemão insistia, no entanto, na perspectiva salvadora que a crise de tradição poderia oferecer à ação histórica do homem: o retorno ao passado perdido, por meio de um jogo lúdico da lembrança e do esquecimento, ideia que nos parece essencial ainda hoje para se compreender o caráter aparentemente difuso ou mesmo pontual das reivindicações juvenis, no qual têm se pautado grandes manifestações de massa como as desencadeadas pela Primavera Árabe, e mais recentemente no Brasil, que fora nomeada por alguns observadores a Primavera Brasileira.

A esse respeito, gostaríamos de trazer para o debate as ideias de um filósofo tcheco, que em 1940 migrou para o Brasil e viveu aqui por cerca de 30 anos - Vilém Flusser. Este autor traz algumas contribuições interessantes para pensarmos a crise da experiência e em que medida as categorias históricas seriam pertinentes para se pensar os fenômenos de massa em países como o nosso, que é o objetivo deste artigo.

A leitura das manifestações juvenis de junho de 2013 encontra-se amparada, de um lado, pela "observação participante" em algumas dessas manifestações em São Paulo, e de outro, no acompanhamento das mesmas em todo o Brasil, por meio da leitura de reportagens e artigos publicados na imprensa oficial e alternativa. Procura-se abordar criticamente as interpretações apresentadas sobre o fenômeno, comparando-o com a Primavera Árabe, inspirando-se na noção de "senso de possibilidade", de Musil, mas principalmente nas ideias de Flusser sobre a "pós-história", ou mesmo nas análises que se tem feito a propósito do papel das "redes sociais" e das "tecnoimagens" no desencadeamento de manifestações de massa lideradas por uma juventude que saiu às ruas para reivindicar novos canais de participação. Estas manifestações, cujos chamados foram feitos por meios virtuais, ganharam, entretanto, corporeidade nas ruas ao serem embaladas por raps e outras músicas de protesto, opondo-se ao "fundamentalismo de mercado" e à "privatização do espaço público", como observara Zizek. Um "novo homem" se anuncia com a criação de um campo para o surgimento de uma intersubjetividade pautada por outras formas 
de viver e de se engajar política e esteticamente, em que se faz presente a força de nossa ancestralidade africana.

\section{A crise dos limites no mundo globalizado: como ficam as novas gerações?}

Em outro artigo (Amaral, 2013) no qual foi abordada a primavera árabe, sustentamos que logo após o fogo e a onda de saques que se alastraram pelas ruas dos subúrbios de Londres em 2011, desencadeados aparentemente pela morte de um jovem negro pela polícia, a socióloga holandesa, naturalizada americana, Saskia Sassen (2011), estudiosa da globalização, em entrevista concedida ao jornal $O$ Estado de São Paulo, comentou que chegáramos a "um tipping point", querendo dizer com isto que havíamos chegado a um ponto crítico. A reportagem pretendia relacionar a revolta em Londres às revoluções no norte da África, às lutas sangrentas na Síria, às manifestações em Tel-Aviv por aluguéis mais baixos e educação gratuita, até às manifestações dos jovens no Chile pela gratuidade do ensino superior. E o interessante é que grande parte destas manifestações eram lideradas por jovens que, segundo a autora, tiveram seu futuro roubado pela economia global e pelo esgotamento dos canais de participação política, os quais se encontram, hoje, completamente limitados.

Embora as situações não sejam totalmente equiparáveis, uma vez que para determinadas parcelas da população as questões se coloquem de modo mais crítico, a entrevistada sustentara que estávamos experimentando as consequências da "lógica excludente da globalização".

Desse modo, contrariamente ao que foi veiculado na imprensa nacional brasileira, os distúrbios em Londres, muito parecidos com aqueles que vimosem Paris em 2009, lembravam, segundo Sassen, os levantes dos jovens americanos, negros e pobres nos anos 1970, que, ao se verem excluídos diante da política recessiva adotada, passaram a quebrar tudo para se fazerem ouvir. Para a autora, a falta de emprego e o corte nos investimentos sociais foram, no passado para os jovens negros americanos e estão sendo no presente para os jovens dos subúrbios de algumas cidades na Europa, o fator significativo para desencadear os protestos.

Outro ponto de contato entre as manifestações nos EUA no passado e nos subúrbios europeus é terem se visto acompanhadas por músicas de resistência e de protesto que clamavam, e ainda clamam, por liberdade e reconhecimento de seus direitos, no seio do qual nasceu e se desenvolveu o movimento hip-hop.

Observou-se ainda que, assim como ocorreu no passado, as revoluções da primavera no norte da África se viram embaladas por movimentos culturais de protesto. E, mais do que isso, se o rap do movimento hip-hop inaugurou o uso da mídia como forma de criar uma cultura de resistência e de protesto, o avanço das redes sociais se tornou fundamental para a série de revoluções desencadeadas no mundo árabe e, como vimos no ano passado, foi responsável pelas manifestações de massa desencadeadas no Brasil pelo Movimento do Passe Livre (MPL).

A revolução na Tunísia que inspirou as demais revoluções e revoltas da Primavera Árabe, foi denominada por Manuel Castells (2013), em seu livro Redes de indignação e esperança, "revolução da liberdade e da dignidade". Tudo começou com a autoimolação de Mohamed Bouazizi, um vendedor ambulante que pôs fogo no seu corpo em frente ao prédio do governo para protestar contra o confisco de sua banca de frutas e legumes pela polícia, depois de recusar-se a pagar propina. Último ato de protesto contra a humilhação a que vinha sendo submetido, que acabou desencadeando manifestações contra a corrupção, a especulação financeira, a polícia violenta e a mídia subserviente. Embalada por canções e slogans contra o governo, o povo reunido na praça promove, finalmente, a derrocada do governo, durante a qual a cantora Emil MathLouthi canta seu Kelmti Horra, uma música de protesto que clama por liberdade de expressão.

No Egito, a revolução de 25 de janeiro de 2011, que destronou o "último faraó e seu séquito" em 18 dias, pondo fim ao regime sangrento de Mubarak, foi desencadeada também por uma série de autoimolações em protesto contra o aumento da comida, que deixara grande parte da população com fome. Segundo Castells (2013), "muitas mulheres, jovens e idosas, várias delas com véus e outras vestidas à 
ocidental, estiveram presentes na praça Tahrir e em outros espaços ocupados, algumas delas com seus filhos. Outra questão importante a ser assinalada é que o islamismo era visto pelas pessoas como 'força regeneradora da política, de esperança, de justiça social e de restauração dos valores morais". "3 O título de uma canção de Ramy Essam, Erhal ("Vai embora"), tornou-se palavra de ordem em diversos países árabes. Durante os protestos da praça Thair, o rapper egípcio Mohammed El Deeb cantou, por sua vez, a revolta de seu povo.

O "Dia de Fúria", na esteira das revoluções tunisiana e egípcia, desencadeou protestos em diversos países do mundo árabe, nos meses de janeiro e fevereiro, envolvendo: Argélia, Líbano, Jordânia, Mauritânia, Sudão, Omã, Iêmen, Bahrein, Líbia, Kuwait, Marrocos, Saara Ocidental, Arábia Saudita e, finalmente, a Síria, cujos desdobramentos genocidas estamos assistindo até o presente momento, sem que as potências estrangeiras se decidam por uma intervenção.

O dia de fúria na Líbia foi celebrado pela música anônima Misrata, emprestando o nome da cidade que foi o marco da resistência anti-Kadafi. Ibn Thabit, nome de um poeta árabe do século VII, foi o pseudônimo escolhido pelo rapper líbio para lançar suas músicas pelas redes sociais, nas quais divulgou o Apelo para a Juventude Árabe, contra o "ignorante coronel" (TORRES, 2001).

Perguntava-nos por que em nosso país as manifestações de repúdio à violência policial, por exemplo, restringiam-se aos jovens excluídos da periferia, terreno em que se produziu o hip-hop brasileiro, cujo protesto era acompanhado por manifestações da população dos bairros mais pobres das metrópoles brasileiras.

Esta pergunta foi feita antes do surgimento das manifestações lideradas pelos jovens no Brasil inteiro desde junho de 2013, desencadeadas por meio das redes sociais. O interessante é que tais manifestações, embora conduzidas por jovens aparentemente de classe média, conseguiram congregar muitos setores insatisfeitos com a qualidade de nossa representação política.

\section{Impressões iniciais sobre os movimentos de rua liderados pelo MPL no Brasil}

A juventude tem uma vantagem em relação às outras idades da vida: ela pode sonhar, como a criança, o impossível ou o improvável, com a diferença de que para ela, urge experimentá-la como possível, convertendo o senso de possibilidade que comanda a fantasia - e, por que não, a utopia - em senso de realidade, não a estabelecida, mas aquela ou aquelas vislumbrada(s) como possível(eis). Eis a marca de manifestações que por ela são desencadeadas, como as que tivemos oportunidade de presenciar desde junho do ano passado, inicialmente em São Paulo, lideradas pelo MPL (Movimento do Passe Livre), cujas bandeiras acabaram se estendendo à luta contra a corrupção, por saúde e educação de qualidade, mas principalmente pelo uso do dinheiro público e do espaço público, guiado pelos princípios da democracia, ampla e irrestrita, velha bandeira dos movimentos sociais pela democratização do Brasil.

Entretanto, nos primeiros atos contra o aumento da tarifa de ônibus e metrô de São Paulo em junho de 2013, diversos jornalistas e formadores de opinião criticaram duramente a mobilização de uma juventude que eles mesmos diziam ser alienada. A opinião expressa pelo comentarista da TV Globo Arnaldo Jabor, em um telejornal, foi amplamente comentada pela contundência com que acusou os jovens manifestantes de "filhos de classe média", cheios de ignorância e rancor, sem verdadeiros motivos para lutar. Eles seriam uma "caricatura violenta" de uma velha esquerda que não valeria os míseros centavos que estavam reivindicando contra o aumento.

Opiniões como esta apenas reforçaram o engajamento dos mais diferentes grupos e pessoas contra a má administração pública, violência policial, manipulação da grande mídia e tantas outras bandeiras que dificultam qualquer classificação de tal fenômeno. A complexificação das manifestações foi acompanhada, paradoxalmente, pela tentativa de tais formadores de opinião de simplificar o conteúdo dos conflitos existentes. Contudo, dias depois, o próprio Jabor teve de admitir o erro de sua análise, mas manteve sua postura moralizante ao propor quais seriam os motivos válidos para a população se manifestar. Para ele, os jovens deveriam lutar por uma República.

3 IBIDEM, p.64. 
Outros analistas aproveitaram o momento de adesão de uma imensa quantidade de pessoas para questionar a militância dos manifestantes. Embora a essa altura fosse temerário para qualquer analista político condenar a ação de tantos sujeitos engajados em uma causa indecifrável, acreditava-se que o movimento nas ruas estava sem rumo. Diante de tamanha força, os motivos dos manifestantes eram vistos como legítimos, prevalecendo, no entanto, a ideia de que os próprios protagonistas desconheciam quais eram as prioridades do movimento. Deste modo, uma parte das análises se distanciava de uma leitura aberta ao novo, que fosse capaz de desprender de parâmetros ultrapassados e categorias históricas, na medida em que estereotipava as iniciativas dos manifestantes e, portanto, não compreendia suas ações concretas. Os debates em redes sociais e em programas de televisão pautavam a discussão sobre o que consideravam ser um "manifestante consciente" dos problemas reais. Em oposição ao bom manifestante - aquele que não é violento - foi enfatizada a figura do "vândalo", atualizando em novas bases a classificação feita por Jabor dos filhos da classe média que, em sua opinião, mereceriam ser presos pela polícia.

Muitos personagens importantes na luta contra a ditadura, que, em maio de 1968, também eram jovens, reconheceram a legitimidade do movimento, mas não sem alguma reprovação em relação às pautas do movimento. Fernando Gabeira, que andava desgostoso com a política brasileira, em uma entrevista concedida a Isto É de 26 de junho de 2013, sentiu-se estimulado por ver nestas manifestações um germe, ainda que embrionário, de renovação, como sugere o termo primavera, adotado em maio de 1968. Gabeira considerou o termo apropriado para essas manifestações, embora não com um significado propriamente político como fora no passado, mas no sentido de que não visava o poder estatal e, sim, o sentido da vida. Seria justamente, segundo Gabeira, a falta de um projeto claro de mudança que poderia abrir espaço para surgir no curso do movimento um novo delineamento de possibilidades e alternativas. Considerava, entretanto, utópica a ideia do passe livre, uma vez que, segundo ele, seria importante reivindicar a melhoria das condições reais do transporte coletivo.

Em um sentido próximo, embora ligeiramente discordante, Marilena Chauí escreveu o artigo As manifestações de junho de 2013 na cidade de São Paulo (Revista Teoria e Debate, set/2013), no qual salientava a legitimidade das reivindicações, para em seguida dar uma verdadeira "lição histórica" para os jovens manifestantes, tanto em relação à pauta específica do passe livre, como em relação ao repúdio e até mesmo à violência empregada por alguns contra a participação da militância partidária. Em relação ao repúdio a esta última, salientou, no entanto, o perigo do surgimento de movimentos conservadores de direita, dada a experiência histórica de totalitarismo do nazifascismo que resultou da supressão dos partidos e organismos de representação de classe, mediações políticas importantes, a seu ver, na relação com o Estado. Quanto à reivindicação do passe livre, relembrou-nos que esta teria sido uma bandeira do governo de Luisa Erundina que propôs um IPTU progressivo, cuja taxa seria mais alta para os imóveis mais ricos, para subsidiar a gratuidade do transporte público. Mas a grita foi geral, afora o fato de se ter que enfrentar o poder do capital de montadoras, empreiteiras e cartéis de transporte. Tudo isso para demonstrar que o pensamento do movimento e, em particular, das lideranças do MPL, era mágico, para não dizer infantil, guiado pelo princípio do prazer, buscando satisfação imediata, o que, do ponto de vista político, resultava na exigência de uma resposta imediata do poder público às suas reivindicações. Em entrevista concedida à Revista CULT n. 182, de agosto de 2013, ponderou, no entanto, ter realmente se surpreendido com o resultado da utilização das redes sociais por parte da liderança do MPL, conseguindo reunir um número tão significativo de pessoas nas ruas, e que faltara aos governantes, até mesmo ao prefeito Haddad, a capacidade de dar uma resposta política ao movimento, convocando-os a pensar juntos sobre o que fazer para atender às reivindicações. Ou seja, convocando-os a uma gestão conjunta do município. Ponderou, desta vez, que o movimento não era de esquerda ou de direita, corria no meio, havendo em torno dele "duas tentativas extremas de apropriação" (referindo-se às extremas esquerda e direita).

Outros intelectuais, como Vladimir Safatle (2013), embora não tivesse se alongado tanto quanto Marilena Chauí, posicionou-se radicalmente contrário a interpretações que desqualificavam a importância de tais manifestações ao taxá-las de totalitárias. Ponderou, ao contrário, que a rejeição aos partidos políticos 
poderia ser interpretada como demonstração da capacidade de inventar mecanismos de democracia direta. São pessoas que, segundo ele, "adquiriram a consciência de sua força política e que não veem razão para transferir tal força para partidos profundamente hierárquicos e guiados pelo raciocínio tático" (SAFATLE, 2013).

Segundo depoimentos de pessoas que participaram dessas manifestações, não eram apenas estudantes de classe média que nada entendiam da violência e miséria vivida na periferia que estavam presentes. Havia sim jovens da periferia, muitos deles frequentando universidade, o que teria sido facilitado pelo Prouni e pelas cotas nas Universidades Federais, que justamente por terem tido acesso a uma formação que, até pouco tempo atrás, lhes fora vedada, passaram a ter clareza de seus direitos, como cidadãos, ao mesmo tempo em que se viam acossados pelas dificuldades financeiras. Estas ainda se constituíam em um impeditivo para a melhoria de suas condições de vida, sendo a questão do transporte um item fundamental.

Tampouco se tratavam de jovens utópicos ou guiados pelo pensamento mágico, como deixa claro Paulo Arantes, em entrevista concedida ao jornal $O$ Estado de São Paulo (Aliás, 23/06/2013, p. E2). O entrevistado ponderou sobre a rapidez e perspicácia de suas lideranças, ao demonstrarem por meio de planilhas como "a circulação urbana planejada à luz de uma tarifa zerada, exponenciaria a performance econômica de uma cidade, e estenderia o direito à cidade". Um raciocínio que aprofunda o sentido de democracia e de cidadania ao defender a bandeira do MPL, que, a nosso ver, ampliaria o direito de circulação ao conjunto da população, além de expor quão fantasiosas pareciam ser as planilhas dos órgãos governamentais.

Ampliemos agora o debate para o campo internacional, recorrendo a análises de "alguém de fora" e "de dentro".

\section{Debate internacional sobre as manifestações de rua lideradas por jovens em todo o mundo}

Slavoj Zizek (2013), em artigo publicado pela London Review of Books, e que foi entrevistado durante a Flip Literária de Paraty pela TV Cultura, no Programa Roda Viva, rompendo com o silêncio europeu sobre as manifestações que se iniciaram com a
Primavera Árabe e mais recentemente atingiram países emergentes, como o Brasil e a Turquia, afirmou que os protestos não tinham um alvo específico - contra o capitalismo global, ou contra o fundamentalismo religioso -, mas que refletiam muito mais um mal-estar, um descontentamento fluido que dava sustentação a diversas demandas específicas. No entanto, admitiu que esse mal-estar era sentido frente a um fundamentalismo que atingia a todos, embora acompanhando a singularidade de cada região ou país: o fundamentalismo de mercado e a consequente privatização do espaço público.

Assim se explicaria como se desencadearam grandes manifestações em torno de questões bem específicas: o fato de o governo islamista, na Turquia, querer transformar o parque em torno da praça Taksim, situada no centro de Istambul, em um shopping center desencadeou manifestações de grandes proporções. No Brasil, um pequeno aumento das tarifas de ônibus levou mais de 100 mil às ruas em cada uma de suas principais cidades. Ora, na verdade, a força e extensão de tais manifestações eram devidas a um mal-estar muito mais profundo em relação aos limites da democracia e do próprio avanço do capitalismo. Sem deixar de observar que em cada boom na economia, como os observados no Brasil e na Turquia, há sempre a permanência de bolsões de miséria.

Ponderou que tais movimentos podem fazer avançar o sentido de democracia quanto mais exigirem o impossível, explorando as contradições do avanço global do capitalismo e, desse modo, indo além da dimensão política, em direção a uma democratização social e econômica.

Uma discussão interessante a esse respeito, que acreditamos poder contribuir para o avanço dessa discussão, é feita por Vilém Flusser em duas obras: Pós-História - vinte instantâneos e um modo de usar (1998) e Fenomenologia do Brasileiro - em busca de um novo Homem (2011).

\section{Flusser e suas ideias a respeito da vacuidade da experiência, pós-história e de um novo homem}

Vilém Flusser, ${ }^{4}$ filósofo nascido em Praga em 1920, fugiu para a Inglaterra durante a invasão nazista

\footnotetext{
4 IBIDEM.
} 
e emigrou para o Brasil, onde viveu por mais de 30 anos. Foi professor da Universidade de São Paulo e colaborador do Estado de São Paulo por longo tempo, onde escrevia sobre Filosofia da Linguagem, e posteriormente da Folha de São Paulo, além de emissário do governo brasileiro para assuntos culturais na Europa e nos EUA.

Embora tenha vivido grande parte de sua vida no Brasil, sua obra passou a ser reconhecida somente depois de sua morte em 1991, com a organização de diversos encontros internacionais na Europa e a publicação de suas obras em cerca de 13 países. No Brasil, no entanto, apenas duas delas foram publicadas: Filosofia da Caixa Preta e este livro, Fenomenologia do Brasileiro, pela Editora da UERJ. Mais recentemente, a Editora ANNABLUME acabou publicando grande parte de suas obras, versando muitas delas sobre a era pós-industrial marcada pelo avanço da cibernética e do pensamento programático, em que os aparelhos passaram a funcionar cada vez mais independentemente dos motivos de seus programadores. Tudo isso tem apontado para mudanças nos campo da experiência, dos relacionamentos e da comunicação.

\section{No campo da experiência}

Flusser (2011), em seu livro Pós-História, sustenta que se antes percebíamos o mundo no contexto de objetos ou de processos, hoje isso se dá no contexto das relações. Não nos deparamos mais com eventos ou situações, mas com um campo de relações, o que acarreta mudanças tanto no plano do conhecimento, quanto da experiência. Ou seja, a mudança dos modelos de conhecimento e da experiência se reflete na transformação da estrutura das relações, que passam a abstrair o "eu" e se basear numa rede que prende o sujeito à sociedade, qual um gancho "sobre o qual as relações que sou estão dependuradas", ${ }^{5}$ De onde se depreende a vacuidade, não apenas dos objetos e processos como da própria existência do mundo.

Deriva dessa leitura uma ontologia relacional que leva, por sua vez, à ética e a comportamentos altruísticos. É como se esse fosse o caminho para a

5 IBIDEM, p. 174. consciência se politizar - o da "intersubjetividade responsável para o outro e pelo outro". ${ }^{6}$ No entanto, salienta o autor, o que se observa é uma "despolitização massificante", uma vez que todos os campos de relações se tornam "ciberneticamente manipuláveis". Tornamo-nos aptos a atar e a desatar as relações e com isso, o jogo social se torna o "jogo do absurdo", uma vez que a sociedade desmantelou sua dimensão mítica e histórica e as des-existencializou. Não há fidelidade possível (esta só se realiza entre pessoas), mas há jogo. O que passa a existir é a fidelidade sem amor, engajamento (ideias, ideologias, etc.). Mas é por meio da consciência do absurdo de nossa existência, que se pode vislumbrar um novo tipo de relacionamento social. É preciso transcender os aparelhos e utilizá-los como jogos, com estratégias intersubjetivas.

Ora, recorremos a este autor justamente porque nos parece que ele fornece outras chaves, para além das categorias históricas, essenciais para se compreender as manifestações juvenis que assolaram o nosso país desde junho do ano passado, cujas reivindicações pareciam apontar para uma crise de confiança não apenas nas instituições, mas em todas as formas de representação. É a conversão do discurso em diálogo. Eis a chave do uso que se fez das redes de comunicação social como estratégia de reunião e de derrubada das formas de poder e de comunicação hierarquizadas. Constituindo-se em redes de indignação e de esperança, como salientara Castells (2013), retomaram a dimensão pública e humana da intersubjetividade, ao se reunirem em ruas e praças.

\section{A consciência pós-histórica e as tecnoimagens}

De acordo com Flusser (2011), o século XIX foi palco da crise da historicidade, tal como anunciara W. Benjamin e outros autores no início do século $\mathrm{XX}$, na medida em que a consciência histórica foi perdendo o chão da experiência, "o contato que os textos estabelecem com o mundo da experiência concreta". ${ }^{7}$ É o momento em que a escrita vai sendo paulatinamente substituída pela fotografia, filmes,

\footnotetext{
6 OP. CIT, p. 174.

7 IBIDEM, p. 117.
} 
vídeos, etc. As tecnoimagens se dirigem contra os textos para liberar a "humanidade da loucura conceitual", segundo o autor. Mas para decifrar as tecnoimagens é preciso outro nível de consciência - a pós-histórica. Há que se considerar que são diferentes das imagens tradicionais, que eram produzidas por homens. Agora são produzidas por aparelhos, "que transcodam sintomas em imagens", "devoram história e vomitam pós-história". 8

Segundo o autor, "os eventos se precipitam rumo ao aparelho com rapidez acelerada, porque estão sendo sugados, e parcialmente provocados pelo aparelho". . "O aparelho se torna a meta da história", diz ele.

Mas a questão é se seria possível transcender tal forma de existência por meio da decifração das tecnoimagens. Para o autor, não será possível transcendê-las por meio da crítica histórica, a não ser dando um passo atrás em direção à programação, desenvolvendo uma espécie de tecnoimaginação presente na cibernética, informática e teoria dos jogos.

Talvez por aí se possa explicar como os jovens do norte da África conseguiram burlar as tentativas de impedir a comunicação e as manifestações do povo contra o governo. No Egito, um fator importante foi que uma jovem blogueira, Asma Mafhouz, de 26 anos, estudante universitária, divulgou esses protestos à juventude egípcia. Em 18/0/01/2011, ela postou um videoblog na página da internet Facebook (CASTELLS, 2013, p.47), a partir do qual alguém o transmitiu pelo canal da internet YouTube, que acabou reunindo milhares de pessoas no dia 25 de janeiro na Praça Tahir (praça da Liberdade), onde resistiram à polícia, convertendo-a em espaço revolucionário. Isso depois de menos de dois anos do lançamento versão em árabe do Facebook, o que permitiu que 5 milhões de usuários tivessem acesso à internet em fevereiro de 2011, sendo que mais de 600 mil foram adicionados nos meses que precederam a revolução.

Realizando ainda outra ordem de "virada de jogo" - do jogo virtual para a reunião na praça, reconectando as subjetividades e desse modo, reinstaurando a dimensão pública da intersubjetividade. Como muito bem salientou Castells:
Conectando redes de contrapoder, os manifestantes ficaram suficientemente poderosos para induzir a desconexão entre importantes redes de poder, enfraquecendo o sistema de dominação e transformando a violência num recurso cada vez mais difícil de empregar para manter o país sob controle (2013, p. 72).

Aqui no Brasil, a violência empregada pela polícia foi respondida com a ampliação do movimento nas ruas em proporções gigantescas, como há muito não se via, atingindo cerca de 350 cidades do país.

\section{Como a ideia de Novo Homem, da Fenomenologia do Brasileiro, ajuda a pensar o devir da cultura}

Em outro livro, Fenomenologia do Brasileiro (1998), Flusser se coloca como um pensador que reflete sobre o homem brasileiro, de dentro e de fora - como brasileiro e migrante. Do conjunto de suas reflexões, interessa-nos discutir dois aspectos: sua compreensão multi-perspectivista da questão da miséria, tema bastante importante em países como o nosso; seu entendimento do homem novo e de como o brasileiro foi capaz de se recriar a ponto de vir a se constituir como uma alternativa que "pode dar origem a uma nova maneira de estar no mundo". ${ }^{10}$

Nossa intenção com esse debate é avaliar sob outro ângulo, à luz das reflexões desse filósofo tcheco, as dificuldades de apreensão do movimento das ruas liderado pelo MPL por parte da intelectualidade e políticos brasileiros.

\section{A propósito da miséria... humana}

O autor relembra-nos o caráter multifacetado que o termo miséria adquire do ponto de vista linguístico: em português, há a conotação de avareza; em alemão, em seu uso antigo, há a significação "viver alienado" (im Elend leben). Com o propósito de pensar filosoficamente sobre o homem brasileiro, reúne estes dois sentidos - avareza e alienação

\footnotetext{
8 OP. CIT. p.118.

9 OP. CIT. p.119.
}

10 IDEM, p. 166. 
- para sustentar que, para além do significado usual ligado a uma carência acentuada do ponto de vista econômico, pode-se pensar que o termo miséria pode muito bem se referir à miséria humana, ou seja, "como resultado da autoentrega alienada a coisas que passam a ser acumuladas para reencontrar-se nelas" (FLUSSER, 1998, p. 113). Nesse sentido, pode-se deduzir que assim como há miséria ligada à carência, há também miséria ligada ao excesso. Neste caso, produz-se uma verdadeira reversão da relação homem-coisa, segundo a qual "o homem deixa de possuir coisas e passa a ser possuído e possesso por elas". ${ }^{11}$ A alienação se faz presente em ambos os casos. No caso da carência, o homem se vê coisificado pelo que lhe falta. E no caso do excesso, é coisificado pela posse de coisas em excesso. Em ambos os casos, a escravidão está presente.

Recorrendo a uma abordagem existencialfenomenológica, opõe-se à visão historicista que tende a ver a miséria apenas no primeiro caso, considerando que falar em miséria por excesso significa querer minimizar a miséria por carência. A seu ver, debruçar-se sobre os dois significados aponta para uma reflexão de outra ordem, ao se referir a uma maneira de ser que se rende ao mundo e se aliena progressivamente de si, que Heidegger teria chamado de "decadente". Dar-se conta de sua existência miserável, pode desencadear uma angústia, que pode tanto aprisionar o sujeito no isolamento coisificado, quanto fazê-lo experimentar a liberdade, ou seja, "a possibilidade de existir no indeterminado, portanto, no futuro". ${ }^{12}$

A partir destas ideias, perguntamo-nos em que medida seria verdadeira a afirmação de que o "Brasil é um país do futuro". Para ele é falsa, do ponto de vista histórico, uma vez que nada aponta nesse sentido. Mas pode ser verdadeira, se pensada existencialmente. Quando o país começa a se preocupar com sua miséria e se vê tomado de angústia, coloca-se "não apenas como país de seu próprio futuro, como do futuro da humanidade". ${ }^{13}$ Mas, como pensador capaz de duvidar, põe em questão essa ideia, propondo-se a analisar o quanto o brasileiro está realmente

11 IDEM, p.113.

12 IBIDEM, 1998, p. 115.

13 OP. CIT. P.115. preocupado e o quanto não passa de euforia passageira. Uma discussão bastante pertinente para se pensar sobre a seriedade e o alcance das manifestações desencadeadas pelo MPL.

Levanta, no entanto, outra dimensão especificamente brasileira, oriunda de sua cultura e diversidade étnica, que pode fazer com que se enfrente a angústia em face da miséria de modo distinto de outras partes do mundo. Considera que até então foram identificadas três formas de enfrentamento da miséria: a primitiva, a ocidental e a oriental. Ocorre que no Brasil é possível identificar-se uma quarta reação. A primeira aborda o modo como as culturas melanésia e maia enfrentaram a miséria, tomada como um dado ecológico da natureza. A ocidental se originou há 8000 anos e tornou-se consciente a partir do Renascimento, apresentando uma tal aceleração do progresso que sofre muito mais por excesso do que por escassez. É o caso da Europa Ocidental e dos EUA. Já a oriental foi construída pela Índia há mais de 4000 anos. Segundo este ponto de vista, miserável é aquele que se assume enquanto tal, fazendo com que o progresso não seja medido segundo critérios considerados objetivos, como calorias ou número de carros produzidos, mas levando em conta também a dimensão subjetiva.

\section{Ora, e no Brasil, como essa questão se coloca?}

Embora a miséria brasileira seja comparável em muitos aspectos à miséria hindu, do ponto de vista de seu enfrentamento, são bem distintas, pois aqui não há uma posição fatalista em relação à miséria como de algum modo pode ser identificado na Índia. Em primeiro lugar, porque aqui as misérias são incomparáveis: há a miséria do caboclo que vive à beira do Rio São Francisco, a miséria da família nordestina em São Paulo, a miséria da mulher proletária, a da mãe proletária, para mencionar algumas das mais importantes. Há a miséria causada por causas naturais e outra, por questões econômicas e culturais. Embora haja uma crença de que o progresso deva ser alcançado no Brasil nos moldes ocidentais, o autor sustenta que se deva visualizar uma solução supra-histórica, convertendo o ideal de progresso em uma meta não progressista que só seria alcançável se “o 
método do progresso fosse aplicado até certo ponto" (FLUSSER, 1998, p. 125).

E parece ser este o projeto brasileiro, que embora esteja impregnado de ideologias, supõe uma meta sui generis: mesmo que se admita a necessidade de liquidar a miséria econômica, há certa tendência a se pensar que o progresso é necessário, mas até certo ponto, uma vez que se prioriza o jogo, a religiosidade e a cultura. Embora seja apenas um esboço de projeto, no momento em que este se torna consciente, poderia ser de extrema importância para toda a humanidade. Ou seja, o aspecto lúdico da cultura brasileira que advém da herança negra, de nossa ancestralidade afro-brasileira, diz o autor.

\section{De onde vem a dominância negra de nossa cultura?}

A despeito das diferenças étnicas, culturais e sociais entre os negros que foram trazidos para $o$ Brasil com o tráfico negreiro, ignorada em grande parte e até mesmo banida pelos escravocratas, a força de suas línguas, costumes e concepções de mundo, assim como da linguagem indígena, com todo o seu rico matizado linguístico e cultural, penetrou de tal modo na língua e visão de mundo dominantes, que acabou criando as condições de surgimento do novo homem. Segundo o autor, as gerações de afrodescendentes, em particular, embora tivessem sido esvaziadas no passado de seus modelos e tradições, mantiveram em sua memória corporal e rítmica sua identidade cultural e seus modelos. Uma forma de transmissão entre as gerações foi a garantia de sua dominância, não apenas no Brasil, mas nas Américas: uma Paideia que transmitia modelos, garantindo o essencial, mas deixando às novas gerações a liberdade de recriar os detalhes. A consequência dessa particularidade em suas formas de transmissão, segundo o autor, "é que as culturas africanas têm estrutura rígida (não histórica), mas grande abertura para a articulação de fortes individualidades" (FLUSSER, 1998, p. 135).

Além disso, sua arte, expressa na música e na dança, não são obras a serem contempladas como é usual no mundo ocidental, mas fazem parte, ao contrário, da vida religiosa e do cotidiano. Com isso, "as culturas africanas a um tempo articulam o sentido da vida do homem e dão sentido ao ambiente humano, que transforma em ambiente de vida" (1998, p. 135). Essa dimensão integrada de tudo que constitui o humano - a arte, a religiosidade e o cotidiano - acabou sendo fundamental para a cultura brasileira. E justamente esse penetrar sorrateiro da força dessa cultura nas camadas profundas de nosso inconsciente nos faz romper com um modo de pensar linear, causal ou mesmo frio e pragmático, como tem predominado entre a burocracia governamental, criando, em oposição a este último, a possibilidade de um novo homem. Este, segundo o autor, seria capaz de romper por dentro, pela língua, a reificação, a objetivação e a alienação. "Um novo homem com a chance, propriamente linguística, portanto existencial, de superar a discursividade linear indogermânica e semítica, reconhecendo-se não mais unidimensional, justo por que vive para além da historicidade do discurso que formou o Ocidente judaico-cristão, ou seja, justo porque se pode admitir vivendo na pós-história" (1998, p.27). Tais afirmações não se coadunam com o debate sobre a pós-modernidade, que considera pouco sério, mera "balela".

\section{Contextualização da ideia de pós-história a partir das manifestações de junho}

O que ocorreu no dia 17 de junho de 2013 na região da Faria Lima foi um marco para os habitantes da metrópole paulistana. Ali houve a concentração de um grande ato contra o aumento da passagem de ônibus e contra a violência policial. O clima divulgado pela mídia era assustador, pois ficou subentendido que a polícia militar não interferiria nos eventuais problemas ocorridos no trajeto da manifestação, em vista da repercussão negativa da atuação policial no ato precedente, ou que tal atuação recrudesceria.

Mas a célebre avenida havia sido amplamente ocupada. Os jornais contabilizavam cerca de $60 \mathrm{mil}$ manifestantes, mas este número soava inverossímil para os que participaram do ato. Esta manifestação teve proporções tão grandes que diversos grupos se dispersaram ao longo da enorme caminhada e, mesmo assim, as vias continuavam tomadas por uma multidão. De modo que era muito difícil fazer uma estimativa da quantidade de pessoas presentes 
e difícil de imaginar que um dia uma mobilização como essa fosse acontecer. O que houve foi uma verdadeira entropia.

Vilém Flusser (2011) já havia proposto a entropia como um elemento metafórico para a compreensão do conceito de pós-história. Este conceito consiste na ideia de que a práxis do homem que vive o período pós-Auschwitz não é mais predominantemente orientada pela linearidade histórica transmitida pelos discursos político, religioso e científico na tradição do pensamento ocidental. Diferentemente da pós-história, a práxis do homem histórico tem exacerbados os sentidos finalístico - religião e política - e causalístico - ciência.

Os sentidos finalístico e causalístico são insuficientes para orientar o homem atual em meio à atordoante realidade pós-histórica, que requer um tipo de conhecimento dialógico, e não apenas discursivo. As boas perguntas que se colocam hoje não dizem respeito ao "para que" finalístico e nem ao "por que" causalístico do sentido de viver, mas ao "como" viver em uma realidade programática do mundo codificado.

Ao contrário do conhecimento discursivo, o conhecimento dialógico reconhece o acaso e o absurdo dos programas que codificam o mundo. Ocorre que a barbárie exemplificada por Auschwitz se deve justamente ao fato que os programadores ignoram que eles mesmos são programados pelos programas que julgam ter criado. O sujeito no mundo codificado toma os signos como realidades dadas, transformando-se em funcionário a serviço de uma razão desumana. A imagem emblemática de tal funcionário é a figura do tecnocrata.

Neste fim da história indesejável, grande parte da população global tenderia a assumir a postura do tecnocrata que faz a manutenção de um aparelho autônomo e desumano. De todo modo, o programa e os programadores não são redutíveis à explicação causalística ou finalística, embora sejam também informados por ambas. A humanização das relações na sociedade pós-industrial requer a abertura para outras experiências de viver que podem ser buscadas na estética e na sabedoria ancestral de culturas não ocidentais, sobretudo a africana.

Portanto, a transformação do mundo codificado pressupõe o engajamento estético. O programador somente deixará de ser programado ao se abrir ao imponderável e ao engajar-se no programa cujas regras são estabelecidas coletivamente, no sentido de promover a intersubjetividade e o diálogo. Trata-se de um jogo criado e jogado por todos, cujas regras são permanentemente transformadas pelos próprios jogadores em prol deles mesmos, trazendo à consciência as arbitrariedades destas regras. Esta seria a virtualidade positiva inscrita na pós-história.

\section{Retomando a discussão sobre as manifestações de rua lideradas por jovens no Brasil e no mundo}

A juventude tem conseguido, com essas manifestações de massa, provocar abalos na velha tendência, apontada por Vilém Flusser, a produzir "fusões estéticas [e políticas] de espíritos alheios", presentes não apenas na burguesia, mas também nas esquerdas, ao importar modelos de fora, transpondo para o Brasil o embate de "forças históricas externas", acreditando que o único campo de batalha possível seja entre o "neocapitalismo" (referindo-se ao capitalismo tardio) e o "socialismo". Ou seja, projetos e categorias de análise em um país em defasagem (em relação às revoluções burguesas históricas, como a americana e a francesa), que sob o manto de uma única língua, o português, deixa-se penetrar por elementos da língua tupi e de línguas africanas, como o bantu. E desse modo, a estrutura arcaica de uma língua é enriquecida por heranças indígenas e africanas, para depois dialogar com a onda sucessiva de influências de migrantes europeus, "de terreno linguístico o mais variado possível - por exemplo, o polonês, o árabe, o japonês, o alemão, o italiano, o ídiche" (FLUSSER, 1998, p. 27); de onde se deduz que não há uma única língua - mas várias línguas e vários mundos.

É justamente dessa variedade de universos e línguas que pode surgir o que o autor chama de um "novo homem", com uma discursividade capaz de romper com a linearidade "indogermânica e semítica" e com o homem unidimensional. Eurocêntrico, diríamos, acompanhando o debate sobre o multiculturalismo, que pretende justamente fazer emergir essas línguas e mundo submersos. Um discurso múltiplo, perspectivista, que se abre para o que o autor 
considera ser a pós-história, ou seja, para além da historicidade do discurso que formou o Ocidente judaico-cristão. Embora não identifique uma tendência messiânica no brasileiro, acredita encontrar-se aqui a possibilidade de transcendência do absurdo que constitui a era atual. E isso desde que não se iluda com as promessas da globalização. Eis o que nos parece emergir das ruas sob a liderança da juventude que arrisca lutar até mesmo contra as "vantagens da copa e das olimpíadas no Brasil”, claramente ilusórias, uma vez que vêm acompanhadas de obras faraônicas e desnecessárias.

Levando em consideração as ideias de autores como Flusser e Zizek, parece-nos que os jovens conseguiram captar essa dimensão do humano identificada primeiramente na fenomenologia do homem brasileiro, o fundamentalismo de mercado, como denominara Zizek, o estágio atual do capitalismo, bem como os nossos governantes, mesmo que ancorados em partidos historicamente de esquerda, têm passado ao largo.

Flusser deixa claro que não é possível compreender esse novo homem que se forja como possibilidade de superação dos modelos ocidentais ou mesmo orientais, recorrendo a categorias históricas como insistem os partidos de esquerda. As categorias marxistas, de luta de classes, por exemplo, são apropriadas para os países históricos, europeus e até norte-americanos, mas não para o Brasil.

A recusa dos jovens aos partidos parece fazer ecoar justamente essa defasagem que não fora captada pelos partidos de esquerda e que de algum modo foi capitalizada pelo movimento liderado pelo MPL.

Mas o que os une às revoluções desencadeadas pela Primavera Árabe, a despeito das diferenças de contexto econômico, político e religioso? Estão lutando pelo aprofundamento do sentido da democracia e contra toda forma de fundamentalismo, ao mesmo tempo em que exigem modelos de desenvolvimento e de "progresso" no ritmo e forma consoantes com as necessidades e costumes de cada povo. E assim, ressignificam o espaço e o interesse públicos.

Uma luta que vem sendo empreendida nos últimos 30 anos pelo movimento hip hop por todo o globo, como sustentamos em artigos e pesquisa realizada sobre o potencial de formação para as novas gerações, propiciada pela dimensão estética e de contestação do movimento.
Embora, na revolução da primavera árabe, tenhamos nos deparado com rappers e seus cantos falados embalando as manifestações de rua, aqui no Brasil, não houve a presença do rap ou do movimento hip hop. E não se pode esquecer que o rap tem sido voz solitária nas denúncias sobre a desigualdade racial, que na esteira das letras das músicas de capoeira e do samba tem denunciado algo que ainda não foi tema dessas manifestações juvenis que se alastraram no Brasil desde junho deste ano, denunciando não apenas o preconceito e a discriminação que pesam sobre o negro, mas principalmente o genocídio praticado contra os mesmos nas periferias, particularmente de metrópoles, como o Rio de Janeiro e São Paulo, pela polícia.

Mas não se pode deixar de considerar que, embora esse debate racial não estivesse em pauta, a juventude nas ruas impôs um debate para a esquerda e as classes dominantes em relação aos velhos modelos e ao histórico embate entre o neoliberalimo e o socialismo, sugerindo ser possível decifrar nas redes de comunicação social algo que está além delas e, ao mesmo tempo, nelas se apoiar para romper com as relações hierarquizadas de poder e conhecimento. Um debate que pode nos servir de guia para "restaurar a dignidade" do humano perante a lógica do absurdo instaurada não apenas pela globalização e a mundialização da cultura, mas por uma existência que se desexistencializou, ao se tornar ciberneticamente manipulável. A felicidade pública comemorada nas praças e ruas das cidades deste país, a despeito da forma violenta com que foi recebida pela polícia e pela mídia, se deu recorrendo aos recursos da internet como jogo - jogo de contrapoderes -, tornando possível que a intersubjetividade fosse reconectada na praça, nas ruas e nas vielas; e, quem sabe, liberando da dominância de uma língua as várias línguas e mundos que a constituem. E no Brasil, reinstaurando a dimensão integrada de tudo que constitui o humano - a arte, a religiosidade e o cotidiano - tão presente nas culturas afro-indígenas que acabou sendo fundamental para a cultura brasileira.

\section{À guisa de conclusão}

O que se observou nos protestos de junho de 2013 em São Paulo são traços de diferentes 
virtualidades. Nessas manifestações, puderam ser verificados tanto elementos promissores quanto elementos de alienação e defasagem - outros dois conceitos formulados por Flusser (1999) - na atuação de grupos radicais de esquerda e de direita. A simpatia do filósofo de origem tcheca pendia mais para a esquerda, mas isso não o impediu de ser crítico dos procedimentos dos jovens revolucionários durante a ditadura no Brasil. Ainda hoje se observa alguns dos anacronismos que o autor identificou no tocante à tentativa de reprodução dos mesmos métodos políticos que abstraiam a realidade concreta dos brasileiros.

Alienação e defasagem descrevem a miséria material ou espiritual de sujeitos de diferentes origens socioeconômicas e a insuficiência de modelos teóricos da tradição histórica europeia para a transposição da realidade brasileira. Na manifestação, o exemplo mais patente de defasagem da abordagem política de partidos de esquerda foi a utilização das mesmas categorias de seus opositores para classificá-los e rotulá-los. Deste modo, aqueles que gritavam "o gigante acordou" de modo contrário aos partidos políticos eram vistos como despolitizados e, em última instância, massa de manobra que atrapalharia o ato contra o governo. Foi comum observar nas redes sociais as palavras "medo" e "frustração" de quem se considerava politizado devido à massificação do movimento. Os prognósticos do movimento eram catastróficos, mesmo com toda a mobilização inédita da atual geração de jovens.

Isso não anula a também organização da dita direita e sua aderência à manifestação. É possível dizer até mesmo que alguns dos pioneiros na adesão da direita eram os próprios policiais infiltrados, chamados de "P1". Outros foram intencionalmente trajados com o verde e amarelo e outros símbolos que remetem aos integralistas. Eles também incitaram brigas e a violência contra os que estavam trajados de vermelho, de modo que sua intenção era desviar a revolta dos outros manifestantes para todos aqueles que ameaçavam o Estado, a começar pelo próprio governo do partido vermelho, o PT.

Contudo, eles não eram a maioria, nem a minoria. Apenas coexistiram ao lado de tantas outras causas, revoltas e engajamentos. Tanto a esquerda quanto a direita tinham dificuldades para classificar o que ocorreu porque realçavam somente os aspectos que lhes eram mais convenientes. A visão de mundo linear/causal informava uma realidade que colocava as pessoas em planos diferentes, quando estavam todos pisando o mesmo asfalto e, em certa perspectiva (que é a mesma do helicóptero ou do drone), estavam formando um único e mesmo fenômeno de massas. Além disso, o diálogo é difícil para quem pensa de acordo com um paradigma estritamente político. Nesse contexto não há abertura para o diálogo e para compreender quem são aquelas pessoas que debutavam em um ato político.

Torna-se difícil para alguém com visão excessivamente política e finalista notar a existência de pessoas alheias aos grupos organizados que, não obstante, fizeram parte da manifestação tanto quanto qualquer outro manifestante. À margem daquela movimentação intensa na avenida havia muitos moradores de rua indiferentes e gente pobre que queria protestar, mas não se juntava à massa e permanecia parada como espectadores de um desfile. No alto dos imponentes prédios da Faria Lima, funcionários acenavam em apoio aos manifestantes ou permaneciam atônitos com a impossibilidade de deixar seus estabelecimentos para voltar para casa em vista das ruas ocupadas. Para cada um dos milhares - quiçá milhões - de pessoas que estiveram envolvidas com a manifestação havia um tipo diferente de engajamento. $\mathrm{O}$ único denominador comum era justamente a participação e a ação que, não importa em que sentido, transformou a cidade e a percepção de seus habitantes sobre a mesma.

Paradoxalmente, a promessa de efetiva transformação do jogo em prol dos jogadores consiste justamente na não idealização destes. A alteridade é de difícil admissão para quem tem uma visão finalística exacerbada. Mas isso não implica na cessão de um posicionamento político. Trata-se, isto sim, de reconhecimento. Este reconhecimento é o que Flusser (2011) diz faltar à "nossa ciência", se referindo à ontologia dominante que separa sujeito e objeto.

De modo que as virtualidades de um novo homem que vive a pós-história não são captáveis por programas que normatizam a atuação política. É vã a tentativa de classificar os manifestantes ou anunciar os melhores rumos para o movimento segundo um discurso fechado em si mesmo. Nem sequer é válida a tentativa de decifrar as causas comuns a todos ou a grande parte dos envolvidos, visto que essas causas são meramente abstrações científica 
ou jornalisticamente manipuláveis. Em todos esses casos, não há o elemento do diálogo, ou seja, do engajamento na realidade tal como se apresenta à experiência com o fim de transformar a situação.

Alguns dos propositores da mudança em São Paulo parecem ter algumas afinidades com o paradigma pós-histórico em sua virtualidade positiva. O Movimento Passe Livre esteve disposto a dialogar com diversos setores, com os grandes meios de comunicação e com os moradores das periferias de São Paulo para empreender mudanças. Por meio de uma comunicação eficiente atingiu um grande contingente de interlocutores. Esta comunicação não se restringiu ao ambiente virtual da internet, ao mesmo tempo em que tal recurso se mostrou extremamente útil para o propósito de angariar sujeitos que perseguiam fins tão diversos. Combinando presença física e divulgação virtual de uma realidade opressora manipulada pela mídia, os integrantes do MPL se dispuseram a um contato autêntico com diversos interlocutores unidos pelo propósito de mudar as regras do jogo impostas por programas desumanos. A questão do direito à circulação e à fruição da cidade fez que alternativas até então pensadas como utópicas passassem a ser seriamente consideradas como, por exemplo, a gratuidade do transporte coletivo.

Ninguém poderia prever o impacto que uma organização como o MPL conseguiria realizar na sociedade; ou prever o recuo do governo frente às demandas da sociedade, principalmente dos setores mais desfavorecidos economicamente; ou o modo como os problemas políticos do país são encarados hoje. Tudo isso possui afinidade com as ideias de virtualidade, de Flusser, e de senso de possibilidade, anunciado por Musil, que não podem e nem precisam ser previstas, visto que a realidade é construída por meio do engajamento no instante presente.

\section{Referências}

AMARAL, M. O rap, a revolução e a educação: do Bronx à primavera árabe. IDE: Psicanálise e Cultura. Publicação da SBPSP, v. 36, n.56, 2013.

ARANTES, P. Entrevista concedida ao jornal O Estado de São Paulo. In: Marsiglia, I. O futuro que passou. Aliás, O Estado de São Paulo, 23/06/2013. p.E2-E3.
BENJAMIN, W. O narrador. In: Textos escolhidos de W. Benjamin, M. Horkheimer, T.W. Adorno, J. Habermas. Coleção Os Pensadores. São Paulo: Abril Cultural, 1980. p. 57-74.

CASTELLS, M. Redes de indignação e esperança: movimentos sociais na era da internet. Rio de Janeiro: Ed. Zahar, 2013.

CHAUÍ, M. As manifestações de junho de 2013 na cidade de São Paulo. Revista Teoria e Debate (online). Edição 116, set/2013. Disponível em: <http://www.teoriaedebate.org. $\mathrm{br} / \mathrm{materias} / \mathrm{nacional} / \mathrm{manifestacoes-de-junho-de-2013-na-}$ cidade-de-sao-paulo?page $=$ full $>$. Acesso em: 22 setembro 2013.

. Pela responsabilidade intelectual e política. Revista CULT, n.182, ano16, , p.07-15, ago.2013.

DUARTE, R. Pós-história de Vilém Flusser: gêneseanatomia-desdobramentos. São Paulo: Ed. Annablume, 2012.

FLUSSER, V. Pós-história: vinte instantâneos e um modo de usar. São Paulo: Ed. Annablume, 2011.

Fenomenologia do brasileiro: em busca de um novo homem. Rio de Janeiro: Ed. UERJ, 1998.

GABEIRA, F. Entrevista concedida à Revista Isto É. In: Lobato, E. É a primavera brasileira. Revista Isto é, n.2275, ano 37, 26 de junho de 2013, p. 6-12.

MUSIL, R. O Homem sem qualidades. Tradução de Lya Luft e Carlos Abbenseth. Rio de Janeiro: Nova Fronteira, 2006.

SAFATLE, V. Entrevista concedida à Revista Carta Capital. In: BONIS, Gabriel. Protestos mostram esgotamento da democracia parlamentar liberal. Revista Carta Capital, 04/07/2013. Disponível em: <http://www.cartacapital.com. $\mathrm{br} /$ politica/protestos-mostram-esgotamento-da-democraciaparlamentar-liberal-defende-safatle-6118.html >. Acesso em: 22/09/2013

SASSEN, S. Entrevista. O Estado de São Paulo, Caderno Aliás, p. J3.25 dezembro 2011.

TORRES, B. Estação das flores. O Estado de São Paulo, C2. 10 setembro 2011.

ŽIZEK, S. Problemas no paraíso: artigo de SlavojŽižek sobre as manifestações que tomaram as ruas do Brasil. Disponível em: <http://blogdaboitempo.com.br/2013/07/05/ problemas-no-paraiso-artigo-de-slavoj-zizek-sobre-asmanifestacoes-que-tomaram-as-ruas-do-brasil/>. Acesso em: 22 setembro 2013.

Recebido em fevereiro de 2013. Aceito em abril de 2014. 